\title{
Nurse roles in antimicrobial stewardship: lessons from public sectors models of acute care service delivery in the United Kingdom
}

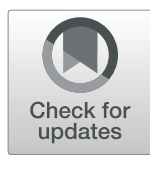

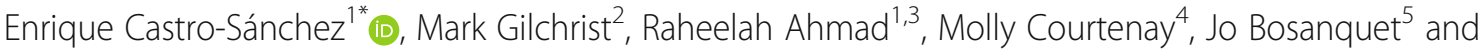
Alison H. Holmes ${ }^{1}$

\begin{abstract}
Background: Health care services must engage all relevant healthcare workers, including nurses, in optimal antimicrobial use to address the global threat of drug-resistant infections. Reflecting upon the variety of antimicrobial stewardship (AMS) nursing models already implemented in the UK could facilitate policymaking and decisions in other settings about context-sensitive, pragmatic nurse roles.

Methods: We describe purposefully selected cases drawn from the UK network of public sector nurses in AMS exploring their characteristics, influence, relations with clinical and financial structures, and role content.

Results: AMS nursing has been deployed in the UK within 'vertical', 'horizontal' or 'hybrid' models. The 'vertical' model refers to a novel, often unique consultant-type role ideally suited to transform organisational practice by legitimising nurse participation in antimicrobial decisions. Such organisational improvements may not be straightforward, though, due to scalability issues. The 'horizontal' model can foster coordinated efforts to increase optimal AMS behaviours in all nurses around a narrative of patient safety and quality. Such model may be unable to address tensions between the required institutional response to sepsis and the inappropriate use of antibiotics. Finally, the 'hybrid' model would increase AMS responsibilities for all nurses whilst allocating some expanded AMS skills to existing teams of specialists such as sepsis or vascular access nurses. This model can generate economies of scale, yet it may be threatened by a lack of clarity about a nurse-relevant vision.

Conclusions: A variety of models articulating the participation of nurses in antimicrobial stewardship efforts have already been implemented in public sector organisations in the UK. The strengths and weaknesses of each model need considering before implementation in other settings and healthcare systems, including precise metrics of success and careful consideration of context-sensitive, resource dependent and pragmatic solutions.
\end{abstract}

Keywords: Antimicrobial stewardship, Nursing, Service delivery, Implementation

\section{Background}

Responding to the global threat of drug-resistant infections (DRIs) demands a blend of wide-ranging yet integrated technical and organisational approaches. Some of these approaches include clinical practice improvements, education and training, surveillance, research and policy [1].

\footnotetext{
* Correspondence: e.castro-sanchez@imperial.ac.uk

${ }^{1}$ NIHR Health Protection Research Unit (HPRU) in Healthcare Associated Infection (HCAl) and Antimicrobial Resistance (AMR) at Imperial College London, Du Cane Road, London, UK

Full list of author information is available at the end of the article
}

Such response to DRIs, however, must also overcome some workforce dilemmas and challenges. On the one hand, there have been proposals for governments, healthcare leaders and other relevant actors to increase funds and boost the number of frontline professionals involved in relevant actions against drug resistance [2]. Alas, the current supply of healthcare professionals worldwide is not robust enough to meet such demands, with shortages of healthcare workers estimated to reach $\sim 13$ million by 2035 [3]. In the UK alone, for example, more than 40,000 nursing positions remain vacant. Therefore, it remains crucial to maximise the contribution of

(c) The Author(s). 2019 Open Access This article is distributed under the terms of the Creative Commons Attribution 4.0 International License (http://creativecommons.org/licenses/by/4.0/), which permits unrestricted use, distribution, and 
existing professional cadres towards appropriate use of antimicrobials.

Among these cadres, nurses represent the largest workforce worldwide. In India, for example, there were just under 4 million nurses in 2016 [4], compared with the 2.95 million nurses practising in the US [5], or the 287,000 full-time equivalent nurses and health visitors in the UK at the end of 2017 [6]. Arguably, any marginal gain -say, $1 \%$ - in the involvement of nurses across optimal management of antibiotics to their full clinical and leadership potential might have a compounded beneficial effect for health services and patients. Such benefits would be particularly welcomed in settings where scarcity of human resources is most acute and the struggle to establish 'more traditional' AMS teams (i.e., those formed by a physician and a pharmacist) more pressing.

Endorsements for the integration or leadership of nurses within AMS interventions have already been made [7, 8]; however, the majority of authors and position statements published have sketched such participation primarily around bedside, clinical, assistive and task-oriented antimicrobial management. Those aspects, although relevant and appropriate, still omit nurses from the wider decisionmaking and executive process and therefore constrain their potential influence and leadership on relevant antimicrobial outcomes [9].

The drivers for such limiting perspective may be multiple, from perceptions within nursing and other healthcare professions about AMS as a mere technical process requiring increased knowledge about antibiotic prescriptions [10] and which therefore broadly excludes professionals without prescribing powers, to existing gaps in undergraduate and postgraduate education about AMS and resistance across human health disciplines [11, 12].

Gradually, though, a variety of interventions such as the standardisation of educational competencies [13, 14] (Table 1) and the regulation of professional AMS tasks $[15,16]$-both aspects crucial considering that effective and sustainable AMS programs demand coordinated efforts from multiple professional groups- have endeavoured to close those gaps and balance their impact.

The maturity now reached by the notion of nurse participation in AMS has also been reflected in some of the

Table 1 Proposed antimicrobial stewardship education domains for undergraduate students in healthcare disciplines in the United Kingdom, [13]

Domain One: Infection prevention and control

Domain Two: Antimicrobials and antimicrobial resistance

Domain Three: The diagnosis of infection and the use of antimicrobials

Domain Four: Antimicrobial prescribing practice

Domain Five: Person centred care

Domain Six: Interprofessional collaborative practice new domains emerging for such participation, ranging from leadership [17], political advocacy [18], or funding of services [19]. (Fig. 1) This progressive inclusion of nurses onto stewardship therefore presents a good opportunity to reflect upon some of the models of AMS nursing already implemented, with a view to facilitate efforts by healthcare workers and decision-makers considering the introduction or expansion of efforts.

\section{Methods}

The paper uses information from purposefully selected, convenience cases drawn from the nationwide network of public sector nurses in AMS in the UK exploring their salient characteristics, strategic influence, managerial and financial relations with other structures, role content and effect on professional identity. The cases were selected to ensure sufficiently rich and contrasting information on their characteristics was obtained, from London/outside London healthcare services, urban and rural organisations, reference and district hospitals, and role components. The cases would help reflect upon lessons and propose models that could be applicable internationally, thus facilitating the implementation of context-sensitive and pragmatic nurse roles.

The network, akin to a special interest group or a community of practice [20], formed organically following the 1st nursing summit in AMS held at Imperial College London in the UK in January 2017. The network currently includes 109 nurses interested in progressing clinical, academic, managerial and educational aspects of nurse involvement in AMS, establishing mechanisms of support for new entrants to the field, fostering collaborations and ultimately encouraging professional visibility at a time of calls for increased nursing leadership in the area [21]. The network has received robust support from clinical and research leaders from pharmacy and medicine. Although the majority of members are based in the UK, there are also professionals from Sweden, Australia, Norway, South Africa, Nigeria and the Netherlands.

The information provided on enrolment to the network by purposively selected cases was mapped against role specifications, scope of practice, governance and organisational profiles (Table 2), with attention to how closely the nurse roles resembled those previously introduced among physicians and pharmacists [22], the setting of jurisdiction and practice for the nurses (community, hospital, acute, long-term care ...), the organisational placing of the role (i.e., whether embedded in infection prevention and control or antimicrobial stewardship pharmacy teams), specific role components (i.e., clinical, educational, quality or service improvement, policy-making, managerial), and measures of role process and outcome evaluation (that is, which indicators would deem the roles as successful). 


\begin{tabular}{|c|c|}
\hline $\begin{array}{l}\text { Pharmacy Influence } \\
\text { - Comprehensive pharmacy assessment } \\
\text { - Drug-drug, drug-patient interactions, PK/PD } \\
\text { - Essential pharmacy care e.g. medication review }\end{array}$ & $\begin{array}{l}\text { Collaborative AMS Responsibilities } \\
\text { - Establish allergy status } \\
\text { - Prescribe within guidelines (MP \& NMP) } \\
\text { - Document indication, dose \& duration } \\
\text { - Administer therapy timely }\end{array}$ \\
\hline $\begin{array}{l}\text { Nursing Influence } \\
\text { - Comprehensive nursing assessment } \\
\text { - Essential nursing care e.g. nutrition, pressure } \\
\text { - Appropriate biological and tissue sampling }\end{array}$ & $\begin{array}{l}\text { - Monitor therapy duration } \\
\text { - Promote appropriate route of administration } \\
\text { - Monitor therapeutic drug levels } \\
\text { - Contribute to preparing patient for OPAT }\end{array}$ \\
\hline $\begin{array}{l}\text { Medical Influence } \\
\text { - Comprehensive medical assessment } \\
\text { - Establish diagnosis, source of infection } \\
\text { - Investigate presenting signs \& symptoms }\end{array}$ & $\begin{array}{l}\text { - Review drug susceptibility } \\
\text { - Educate and involve patients and citizens } \\
\text { - Advocate for AMS programmes \& interventions } \\
\text { - Promote integration with other programmes (sepsis, hand hygiene, IPC) }\end{array}$ \\
\hline
\end{tabular}

Fig. 1 Suggested roles and responsibilities for medical, pharmacy, and nursing staff as part of a stewardship team (adapted from [19])

\section{Results}

Nursing involvement and participation in stewardship has adopted three broad yet distinct models (Table 3), in close alignment with other clinical areas where innovative roles and competencies have appeared [23-26].

\section{'Vertical' model}

Within this model, the participation of nurses in AMS efforts would be channelled via the implementation of a consultant nurse or advanced nurse practitioner role in AMS. The focus of this novel and often unique position would be AMS. In the UK, 'consultant nurse' roles were introduced 20 years ago structured around four core functions of expert practice of high autonomy; education, training and development; professional leadership to motivate others; service development, research and evaluation [27].

Due to these characteristics and aspirations, the roles may be ideal to transform organisational AMS practice. Beyond the creation or commissioning of the post,

Table 2 Domains of antimicrobial stewardship nursing model analysis

Interprofessional working: Considers whether interprofessional working (working with and across professions) is required for the role within the model.

Strategic influence and relation with other structures, teams or services: Defines the likely influence of the model at strategic and organisational level, as well as the position of role holders in relation to other organisational or professional structures.

Clinical outcomes: Describes whether changes resulting from introduction of model would reflect impact or process achievements.

Individual identity: Examines the role archetype used within the antimicrobial stewardship nursing model (i.e. consultant nurse-type, specialist nurse-type, or staff nurse-type).

Funding/Managerial structures: Describes managerial and supervisory responsibility for nurses, as well as the kind of funding (pilot, short-term, etc. ...) and accountability for appointing the workers.

Setting of practice: Hospital, community, long-term care, nursing home facilities ...

Role components: Includes clinical, educational, quality improvement, policy, and managerial components. however, the overall structures for involvement and delivery of nursing input on stewardship would not be transformed at large and any clinical effect or improvement achieved stems from this expert, highly-specialised and influential individual [28].

The appointment of such figure would demonstrate organisational commitment and endorsement to improved AMS performance, and galvanise and rationalise efforts in AMS. Further, the introduction of this focal person in a position of decision-making and influence may legitimise the participation of nurses in AMS, in particular if the main remit of the role is designing, improving or leading practice. Without such guiding figure it may be challenging for nurses to engage in effective AMS, as seen in other areas such as infection prevention and control [29]. As this model would replicate organisational structures existing in other health professions involved in AMS decisions and management, integration within current clinical responsibilities and engagement of other professionals may be easier.

Potentially, though, generating hard evidence of positive outcomes or benefits achieved by the introduction of a single role or individual may be difficult. For example, consultant nurses have so far made their greatest impact in practice and service development and as knowledge brokers [30], rather than in direct patient outcomes and cost-benefit [31] thus being much more challenging to demonstrate such impact when any effect is achieved through the work of others. In antimicrobial decision-making, though, the emerging importance of behaviours such as persuading prescribers together with the social dynamics that end up shaping prescriptions has been gradually recognised [32], offering an ideal target for such advisory and influencing role. This also seems to have been the case with Consultant Pharmacists in Infection and AMR in the UK, encouraging the learning from previous experiences and across disciplines [33].

This hypothetical bottleneck in the translation from role to benefits could also hamper the scalability of the 
Table 3 Characteristics of antimicrobial stewardship nursing models

\begin{tabular}{|c|c|c|c|c|c|c|c|}
\hline \multicolumn{8}{|l|}{ Domains } \\
\hline $\begin{array}{l}\text { Antimicrobial } \\
\text { stewardship } \\
\text { nursing } \\
\text { model }\end{array}$ & $\begin{array}{l}\text { Interprofessional } \\
\text { working }\end{array}$ & $\begin{array}{l}\text { Strategic influence- } \\
\text { Relation with other } \\
\text { structures }\end{array}$ & $\begin{array}{l}\text { Clinical outcomes } \\
\text { (What measure of } \\
\text { impact? Process?) }\end{array}$ & Individual identity & $\begin{array}{l}\text { Funding/ } \\
\text { Managerial } \\
\text { structures }\end{array}$ & $\begin{array}{l}\text { Setting of } \\
\text { practice } \\
\text { (hospital, } \\
\text { community } \\
\ldots \text { ) }\end{array}$ & $\begin{array}{l}\text { Role } \\
\text { components } \\
\text { (clinical, } \\
\text { educational, } \\
\text { quality, policy, } \\
\text { managerial) }\end{array}$ \\
\hline $\begin{array}{l}\text { Vertical } \\
\text { (i.e. nurse } \\
\text { consultant) }\end{array}$ & Yes & $\begin{array}{l}\text { High strategic } \\
\text { influence; focal } \\
\text { relation with } \\
\text { comparable figures/ } \\
\text { roles within own } \\
\text { profession (i.e. nurse } \\
\text { consultant) or others } \\
\text { (i.e. pharmacy } \\
\text { consultant); } \\
\text { collaboration/ } \\
\text { leadership across } \\
\text { aligned areas (i.e. } \\
\text { AMS \& IPC/AMS \& } \\
\text { sepsis etc) }\end{array}$ & $\begin{array}{l}\text { May be difficult to } \\
\text { robustly attribute } \\
\text { impact or clinical } \\
\text { improvements to } \\
\text { the role in view of } \\
\text { indirect work (i.e. } \\
\text { influencing others) } \\
\text { Feasible to } \\
\text { attribute process } \\
\text { improvements }\end{array}$ & $\begin{array}{l}\text { Novel professional } \\
\text { figure/role, } \\
\text { supported by } \\
\text { similar professionals } \\
\text { in other clinical } \\
\text { areas, or } \\
\text { professionals from } \\
\text { other disciplines }\end{array}$ & $\begin{array}{l}\text { Mainstream } \\
\text { human resources } \\
\text { funding } \\
\text { May be difficult } \\
\text { to evaluate value- } \\
\text { for-money } \\
\text { Appointed by } \\
\text { board-level } \\
\text { managers from } \\
\text { own or other } \\
\text { professions }\end{array}$ & $\begin{array}{l}\text { Hospital or } \\
\text { community, } \\
\text { but most } \\
\text { likely } \\
\text { hospital }\end{array}$ & $\begin{array}{l}\text { All, with } \\
\text { emphasis on } \\
\text { planning/ } \\
\text { evaluation/ } \\
\text { management } \\
\text { of } \\
\text { organisational } \\
\text { practice }\end{array}$ \\
\hline $\begin{array}{l}\text { Hybrid } \\
\text { (i.e. nurse } \\
\text { specialist) }\end{array}$ & Yes & $\begin{array}{l}\text { Some strategic } \\
\text { influence as part of } \\
\text { specialist services; } \\
\text { advisory relation with } \\
\text { own and other } \\
\text { professions across } \\
\text { multiple areas }\end{array}$ & $\begin{array}{l}\text { Easy to attribute } \\
\text { impact or clinical } \\
\text { improvements } \\
\text { due to focus on } \\
\text { planning and } \\
\text { delivery of clinical } \\
\text { services, } \\
\text { education. }\end{array}$ & $\begin{array}{l}\text { Traditional role with } \\
\text { some expanded or } \\
\text { novel skills/ } \\
\text { responsibilities } \\
\text { which may have } \\
\text { been jurisdiction of } \\
\text { other professionals } \\
\text { or disciplines }\end{array}$ & $\begin{array}{l}\text { Funding may be } \\
\text { short-term or pilot } \\
\text { before substantive, } \\
\text { based on results. } \\
\text { Appointed by } \\
\text { manager or lead } \\
\text { of specialist team, } \\
\text { which may not } \\
\text { be a nurse (i.e. } \\
\text { consultant } \\
\text { pharmacist or } \\
\text { physician in AMS) }\end{array}$ & $\begin{array}{l}\text { Hospital or } \\
\text { community }\end{array}$ & $\begin{array}{l}\text { All, with } \\
\text { mixture of } \\
\text { planning, } \\
\text { evaluation } \\
\text { and delivery } \\
\text { of services }\end{array}$ \\
\hline $\begin{array}{l}\text { Horizontal } \\
\text { (i.e. staff } \\
\text { nurse) }\end{array}$ & No & $\begin{array}{l}\text { Limited or minimal } \\
\text { strategic influence; } \\
\text { most relations within } \\
\text { own ward/team, with } \\
\text { frequent contact } \\
\text { with specialist/ } \\
\text { advisory roles (i.e. IPC } \\
\text { specialists) }\end{array}$ & $\begin{array}{l}\text { Feasible to } \\
\text { attribute impact } \\
\text { or clinical } \\
\text { improvements in } \\
\text { antimicrobial } \\
\text { stewardship } \\
\text { interventions } \\
\text { deployed }\end{array}$ & $\begin{array}{l}\text { Traditional role, } \\
\text { supported by } \\
\text { similar professionals } \\
\text { in same or other } \\
\text { clinicals areas }\end{array}$ & $\begin{array}{l}\text { Mainstream } \\
\text { human resources } \\
\text { funding. } \\
\text { Appointed by } \\
\text { ward manager/ } \\
\text { nurse in charge }\end{array}$ & $\begin{array}{l}\text { Hospital or } \\
\text { community }\end{array}$ & $\begin{array}{l}\text { Mainly clinical, } \\
\text { educational, } \\
\text { quality and } \\
\text { managerial } \\
\text { service } \\
\text { delivery }\end{array}$ \\
\hline
\end{tabular}

model and affect assumptions underpinning economic evaluations in view of the substantial start-up, upfront implementation costs required (i.e., setting up the role could be expensive) before realising any gains on AMS outcomes. Regarding expenditures, decision-makers may wish to account for any opportunity costs and avoid inefficiencies by reducing or eliminating potential overlapping areas with other professionals.

Finally, there could be a danger of reinforcing multi- but not inter-disciplinarity, by fostering parallel professional lines where a nurse, for example, would address and engage with nursing practices, whilst other professionals supervise and support their own cadres, in tune with existing evidence about social and team demarcations in antimicrobial prescribing [34]. To mitigate such fragmentation, a priori efforts would be vital to identify boundaries and relations between the spheres of responsibility and influence of the new role and others, for example between infection prevention and control, or specialist sepsis nurses [35].

\section{'Horizontal' model}

Within this approach there would not be any specific or dedicated AMS nurse role implemented. Instead, the organisation would engage in a concerted drive to increase optimal AMS behaviours and practices among nurses. Such behaviours may reflect nationally agreed objectives [36] (Table 4), or conform to local needs.

This institutional perspective may serve to distance AMS from the point of prescription or decision-making about prescribing to a broader panoply of tasks, behaviours and decisions framed around the idea of providing excellent care. Doing so would address the recognised chasm between the awareness about AMS, a label hardly recognised by nurses [37], and many clinical tasks performed routinely - for example, ensuring that adequate and biological samples are sent on time for analysis, administering antibiotics doses on time, or communicating to the multidisciplinary team clinical improvements in the patient's condition so alternative, less invasive therapy can 
Table 4 Components of 'Start Smart then Focus', [36]

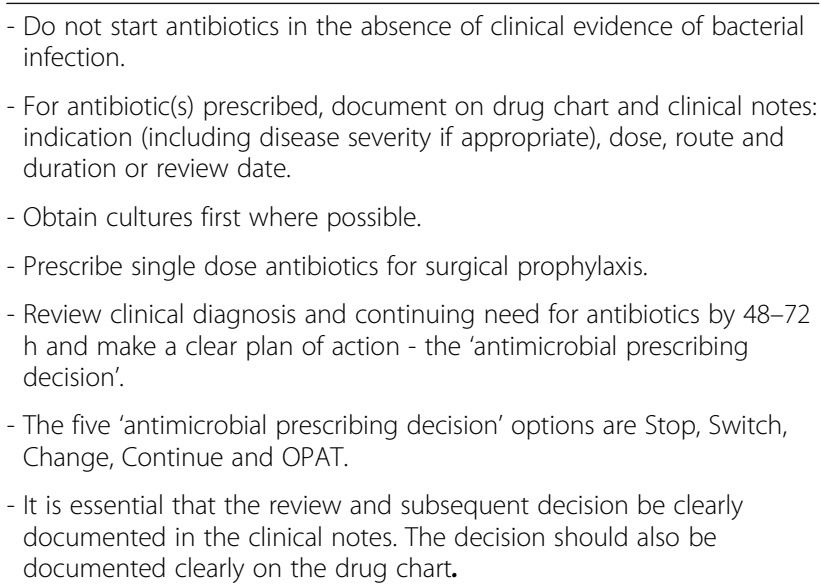

be considered or stopped-, which account for most elements embedded in AMS and are central to quality care. Such point of view may also facilitate constructing a meaningful and engaging narrative for nurses, who may be much more receptive to messages framed around patient safety and quality than prescribing [38].

A great strength of this model would lie on its scalability and potential size and speed of its impact. For example, protocols and directives reflecting centrallydriven priorities about antimicrobial performance may be adopted with relative ease and therefore transform clinical practice without delay $[39,40]$. In reality, such mandates tend to be met with organisational friction which undermines their effect, unless there is an adequate allocation of resources and responsibilities for one or several individuals in charge of the design, implementation, adoption and evaluation of these AMS tasks and responsibilities across the organisation and the nursing workforce [41] (Table 5).

In addition to the organisational friction, the horizontal model may have difficulties resolving competing tensions between existing paradigms within current antimicrobial management, with the response to sepsis demanding swift use of antibiotics whilst stewardship warrants a judicious, perhaps more measured, approach. Without a focal nursing figure establishing an integrative vision that recognises optimal use as the key behaviour (that is, prompt when needed yet promptly reviewed to determine whether its need remains relevant), nurses may not be able to engage in such nuanced performance.

\section{'Hybrid model' (vertical-horizontal)}

Within this model, organisations would foster and implement expectations about increased AMS tasks, roles, responsibilities embedded within the remit of all clinicians including nurses, underpinning such expectations with the allocation to existing healthcare workers of some expanded or specialist AMS skills. This approach could benefit from enhancing existing roles, such as infection prevention and control link nurses, or including further skills and responsibilities within existing specialist nursing teams - sepsis specialist nurses, or nurses in vascular access team would appear particularly well placed to embrace these additional responsibilities. Other posts such as ward managers could combine their leadership in infection prevention and control with an emphasis on stewardship.

This model would offer benefits due to the economies of scale derived from the use of a sizeable portion of the workforce, and natural links with existing roles. However, such rewards may stall due to a lack of clarity about a nurse-relevant vision to drive continued improvement, compounded by an increased complexity of the management of drug-resistant infections.

\section{Discussion}

The broadening and expansion of nursing posts in AMS could strengthen existing programs [42]. However, the mere introduction of any roles -even if coupled with the development of associated educational competenciesmay not be sufficient to stimulate benefits to patients, organisations and the wider healthcare economy.

A crucial aspect to realise these benefits would be the substantiation of clear, concrete, and precise markers of success for such nursing participation, ideally concerned about impact or outcomes rather than just process, in line with the current debate about optimal antimicrobial prescribing, for example [43, 44]. The challenges highlighted in the recent CDC/ANA White Paper [45] related to the existing absence of metrics that could reflect the benefit of incorporating nurses onto service delivery structures has to be acknowledged, and should encourage reflection at the local and national level, depending on the needs and resources available. Recent AMS experiences reported in rural and remote areas in Australia [46] validate the acute need to tailor interventions to the local context.

Although comparable analyses of AMS nursing models in the UK or elsewhere are lacking, it would be possible to apply our findings to some of the existing literature describing the relation of nurses with existing AMS interventions. For example, in their survey exploring the participation of nurses in stewardship across the African continent Bulabula et al. (2018) [47] advocate for expanding the role of clinical nurses to support stewardship, particularly in rural areas, an idea that aligns completely with the horizontal model of wide addition of skills and knowledge to the existing workforce. Further, these authors recognise how existing IPC nurses may also already attend AMS committees and input on policy and clinical decisions, a scenario fitting to our hybrid model of practice. Another example of such hybrid 
Table 5 Examples of antimicrobial stewardship nursing posts from UK network

\begin{tabular}{|c|c|c|c|c|c|c|c|}
\hline \multicolumn{8}{|l|}{ Domains } \\
\hline $\begin{array}{l}\text { Antimicrobial } \\
\text { stewardship } \\
\text { nursing } \\
\text { posts* }\end{array}$ & $\begin{array}{l}\text { Interprofessional } \\
\text { working+ }\end{array}$ & $\begin{array}{l}\text { Strategic influence- } \\
\text { Relation with other structures }\end{array}$ & $\begin{array}{l}\text { Clinical } \\
\text { outcomes- } \\
\text { (What measure } \\
\text { of impact? } \\
\text { Process?) }\end{array}$ & $\begin{array}{l}\text { Individual } \\
\text { identity }\end{array}$ & $\begin{array}{l}\text { Funding/ } \\
\text { Managerial } \\
\text { structures }\end{array}$ & $\begin{array}{l}\text { Setting of } \\
\text { practice } \\
\text { (hospital, } \\
\text { community...) }\end{array}$ & $\begin{array}{l}\text { Role } \\
\text { components } \\
\text { (clinical, } \\
\text { educational, } \\
\text { quality, policy, } \\
\text { managerial) }\end{array}$ \\
\hline Nurse 1 & Yes & $\begin{array}{l}\text { Relation with infection } \\
\text { prevention and control, } \\
\text { pharmacy } \\
\text { Evolving role focus on } \\
\text { Carbapanemase-producing or- } \\
\text { ganism screening }\end{array}$ & Process & Staff Nurse & $\begin{array}{l}\text { Infection } \\
\text { Prevention \& } \\
\text { Sepsis Team, } \\
\text { Nursing } \\
\text { Directorate } \\
\text { Substantive } \\
\text { position }\end{array}$ & Hospital & Education \\
\hline Nurse 2 & Yes & $\begin{array}{l}\text { Relation with infection } \\
\text { prevention and control, } \\
\text { pharmacy }\end{array}$ & Process & Staff nurse & $\begin{array}{l}\text { Infection } \\
\text { prevention and } \\
\text { control, } \\
\text { previously in } \\
\text { pharmacy } \\
\text { Substantive } \\
\text { position }\end{array}$ & Hospital & $\begin{array}{l}\text { Clinical, } \\
\text { education }\end{array}$ \\
\hline Nurse 3 & Yes & $\begin{array}{l}\text { Relation with infection } \\
\text { prevention and control, } \\
\text { pharmacy, antimicrobial } \\
\text { stewardship team, university }\end{array}$ & $\begin{array}{l}\text { Clinical } \\
\text { outcomes, } \\
\text { patient } \\
\text { satisfaction, } \\
\text { process }\end{array}$ & $\begin{array}{l}\text { Advanced } \\
\text { nurse } \\
\text { practitioner }\end{array}$ & $\begin{array}{l}\text { Infection } \\
\text { Prevention and } \\
\text { control/ } \\
\text { University } \\
\text { Substantive } \\
\text { position }\end{array}$ & Hospital & $\begin{array}{l}\text { Clinical, } \\
\text { education, } \\
\text { policy, } \\
\text { managerial }\end{array}$ \\
\hline Nurse 4 & Yes & $\begin{array}{l}\text { Relation with infection } \\
\text { prevention and control, } \\
\text { antimicrobial stewardship } \\
\text { team }\end{array}$ & $\begin{array}{l}\text { Clinical } \\
\text { outcomes, } \\
\text { patient } \\
\text { satisfaction, } \\
\text { process }\end{array}$ & Lead nurse & $\begin{array}{l}\text { Antimicrobial } \\
\text { stewardship } \\
\text { team } \\
\text { Initial 1-year } \\
\text { funding, then } \\
\text { substantive } \\
\text { position }\end{array}$ & $\begin{array}{l}\text { Community } \\
\text { and long-term } \\
\text { care facilities }\end{array}$ & $\begin{array}{l}\text { Clinical, } \\
\text { education, } \\
\text { policy }\end{array}$ \\
\hline Nurse 5 & Yes & $\begin{array}{l}\text { Relation with infection } \\
\text { prevention and control, } \\
\text { antimicrobial stewardship } \\
\text { team }\end{array}$ & Process & Staff nurse & $\begin{array}{l}\text { Antimicrobial } \\
\text { stewardship } \\
\text { team. } \\
\text { Substantive } \\
\text { position }\end{array}$ & Hospital & Clinical \\
\hline Nurse 6 & Yes & $\begin{array}{l}\text { Relation with infection } \\
\text { prevention and control, and } \\
\text { sepsis teams, but mainly on } \\
\text { education for nurses }\end{array}$ & $\begin{array}{l}\text { Clinical } \\
\text { outcome, } \\
\text { process }\end{array}$ & $\begin{array}{l}\text { Staff nurse } \\
\text { based } \\
\text { within } \\
\text { pharmacy }\end{array}$ & $\begin{array}{l}\text { Antimicrobial } \\
\text { stewardship } \\
\text { team }\end{array}$ & Hospital & $\begin{array}{l}\text { Clinical, } \\
\text { quality } \\
\text { improvement }\end{array}$ \\
\hline
\end{tabular}

*None of these roles exemplify the 'horizontal' approach theorised in the paper. +Equally, all roles explored work closely with other professions

practice appears in a qualitative study conducted in the US [48] documenting the engagement of nurses in optimising the use of antibiotics in intensive care units. The authors propose that existing advanced nurse practitioners embrace AMS leadership roles, so the involvement of other nursing colleagues is galvanized and sustained.

Within the UK network the appointment of single professionals on short, fixed-term contracts could be of concern and raise doubts about the likelihood of achieving meaningful clinical and organisational impacts. Such short-term appointing may reflect the business reality of attempting to create new positions. However, as the evidence mounts of benefits related to the participation of nurses, the focus should instead be placed on how best implement new roles or responsibilities rather than, in effect, whether to deploy them.

Additionally, decision-makers evaluating whether to fund and support nurse roles in AMS ought to elude potential unintended consequences derived from such appointments. For example, it would be paramount for AMS not be seen as an isolated, specialist issue that is better handled by specialists, therefore leading to the de-skilling [49] or disinterest from the generalist nursing workforce. As seen in medical practice [50], non-specialist practitioners are still greatly involved in, and remain responsible, for the majority of AMR-related actions.

In fact, the existing narrative and experiences about AMS nursing have mainly involved secondary care, with a handful of experiences in community and long-term 
facilities [51]. Considering that the largest proportion of antibiotics are prescribed in primary care and that nurses are responsible for delivering most services, such imbalance requires urgent attention. The current political emphasis on universal health coverage supported by robust nursing leadership may offer an optimal prospect for studies of community stewardship roles.

\section{Conclusion}

In summary, pressing clinical demands imposed by antimicrobial resistance require organisational responses that would be remiss to ignore the contribution that nurses can have. Optimal approaches to incorporate such contribution remain to be agreed upon, in particular the executive and leadership rather than the clinical facets of the nurse participation in AMS. Although solutions should be context sensitive, resource dependent and pragmatic, the horizontal model of AMS nursing may allow for rapid system-level engagement and linkage to existing structures such as AMS pharmacist, which would facilitate mutual support in achieving AMS goals.

\section{Abbreviations}

AMS: Antimicrobial stewardship; ANA: American Nurses Association; CDC: Centers for Disease Control and Prevention; DRI: Drug-resistant infections; SSTF: Start Smart Then Focus; UK: United Kingdom

\section{Acknowledgments}

The authors are grateful to the network of nurses in antimicrobial stewardship in the UK for their help and support.

\section{Authors' contributions}

ECS was responsible for the study design, data extraction and analysis. MG contributed to the analysis. ECS, MG, RA, MC, JB and AH contributed to the writing of the manuscript. All authors read and approved the final manuscript.

\section{Funding}

This work was supported by the National Institute for Health Research Health Protection Research Unit (NIHR HPRU) [HPRU-2012-10047] in Healthcare Associated Infection and Antimicrobial Resistance at Imperial College London in partnership with Public Health England. ECS is a National Institute for Health Research Senior Nurse and Midwife Research Leader, and acknowledges the support of the NIHR Imperial Patient Safety Translational Research Centre.

\section{Availability of data and materials}

Not applicable.

\section{Ethics approval and consent to participate}

The study used public information available at the nationwide network of nurses in antimicrobial stewardship and was therefore exempt from ethical approval.

\section{Consent for publication}

Not applicable.

\section{Competing interests}

The authors declare no competing interest related to this work. The views expressed are those of the author(s) and not necessarily those of the National Health Service, the NIHR, the Department of Health and Social Care or Public Health England.

\section{Author details}

${ }^{1} \mathrm{NIHR}$ Health Protection Research Unit (HPRU) in Healthcare Associated Infection (HCAl) and Antimicrobial Resistance (AMR) at Imperial College London, Du Cane Road, London, UK. ${ }^{2}$ Imperial College Healthcare NHS Trust, London, UK. ${ }^{3}$ Business School, Management Department, Imperial College London, London, UK. ${ }^{4}$ School of Health Sciences, Cardiff University, Cardiff, UK. ${ }^{5}$ Antimicrobial Resistance Programme, Public Health England, London, UK.

Received: 31 May 2019 Accepted: 9 October 2019

Published online: 22 October 2019

\section{References}

1. Dyar OJ, Huttner B, Schouten J. Pulcini C; ESGAP (ESCMID study Group for Antimicrobial stewardshiP). What is antimicrobial stewardship? Clin Microbiol Infect. 2017;23(11):793-8. https://doi.org/10.1016/j.cmi.2017.08.026.

2. The Review on Antimicrobial Resistance Final report. [Accessed at http:// amr-review.org/Publications]. Accessed 11 May 2019.

3. Campbell J, Dussault G, Buchan J, Pozo-Martin F, Guerra Arias M, Leone C, Siyam A, Cometto G. A universal truth: no health without a workforce. In: Forum Report, Third Global Forum on Human Resources for Health. Recife, Geneva: Global Health Workforce Alliance and World Health Organization; 2013.

4. World Health Organization. World Health Statistics 2011. Geneva: World Health Organization; 2012. Accessed at https://www.who.int/whosis/ whostat/EN_WHS2011_Full.pdf?ua=1.

5. Total Number of Professionally Active Nurses. [Accessed at https://uww.kff.org/ other/state-indicator/total-registered-nurses/?currentTimeframe=0\&sortModel=\% 7B\%22colld\%22:\%22Location\%22,\%22sort\%22:\%22asc\%22\%7D]. Accessed 23 May 2019.

6. NHS Statistics, Facts, and Figures. [Accessed at https://www.nhsconfed.org/ resources/key-statistics-on-the-nhs]. Accessed 05 May 2019.

7. Olans RN, Olans RD, DeMaria A. The critical role of the staff nurse in antimicrobial stewardship: unrecognized, but already there. Clin Infect Dis. 2016;62(1):84-9. https://doi.org/10.1093/cid/civ697.

8. Olans RD, Olans RN, Witt D. Good nursing is good antibiotic stewardship. Am J Nurs. 2017;117(8):58-63.

9. Edwards R, Drumright LN, Kiernan M, Holmes A. Covering more territory to fight resistance: considering nurses' role in antimicrobial stewardship. J Infect Prev. 2011;12:6-10.

10. Castro-Sánchez E, Bennasar-Veny M, Smith M, Singleton S, Bennett E, Appleton J, et al. European Commission guidelines for the prudent use of antimicrobials in human health: a missed opportunity to embrace nursing participation in stewardship. Clin Microb Infect. 2018;24(8):914-5.

11. Castro-Sánchez E, Drumright LN, Gharbi M, Farrell S, Holmes AH. Mapping antimicrobial stewardship in undergraduate medical, dental, pharmacy, nursing and veterinary education in the United Kingdom. PLoS One. 2016; 11(2):e0150056. https://doi.org/10.1371/journal.pone.0150056.

12. Rawson TM, Butters TP, Moore LS, Castro-Sánchez E, Cooke FJ, Holmes $\mathrm{AH}$. Exploring the coverage of antimicrobial stewardship across UK clinical postgraduate training curricula. J Antimicrob Chemother. 2016; 71(11):3284-92.

13. Courtenay M, Lim R, Castro-Sanchez E, Deslandes R, Hodson K, Morris G, et al. Development of consensus-based national antimicrobial stewardship competencies for UK undergraduate healthcare professional education. J Hosp Infect. 2018;100(3):245-56. https://doi.org/10.1016/j.jhin.2018.06.022.

14. Dyar OJ, Beović B, Pulcini C, Tacconelli E, Hulscher M, Cookson B. ESCMID generic competencies working group. ESCMID generic competencies in antimicrobial prescribing and stewardship: towards a European consensus. Clin Microbiol Infect. 2018. https://doi.org/10.1016/ j.cmi.2018.09.022.

15. WHO. Competency framework for health workers' education and training on antimicrobial resistance. Geneva: World Health Organization; 2018.

16. Pulcini C, Binda F, Lamkang AS, Trett A, Charani E, Goff DA, et al. Developing core elements and checklist items for global hospital antimicrobial stewardship programmes: a consensus approach. Clin Microbiol Infect. 2018. https://doi.org/10.1016/j.cmi.2018.03.033.

17. Manning ML, Gianuzzi D. Keeping patients safe: antibiotic resistance and the role of nurse executives in antibiotic stewardship. J Nurs Admin. 2015;45(2):67-9. 
18. Carlet J, Pulcini C, Piddock LJ. Antibiotic resistance: a geopolitical issue. Clin Microbiol Infect. 2014;20(10):949-53. https://doi.org/10.1111/1469-0691. 12767.

19. Castro-Sánchez E, Gilchrist MJ, McEwen J, Smith M, Kennedy H, Holmes A. Antimicrobial stewardship: widening the collaborative approach. J Antimicrob Stewardship. 2017;1(1):29-37.

20. Ranmuthugala G, Plumb JJ, Cunningham FC, Georgiou A, Westbrook Jl, Braithwaite J. How and why are communities of practice established in the healthcare sector? A systematic review of the literature. BMC Health Serv Res. 2011;11:273. https://doi.org/10.1186/1472-6963-11-273.

21. International Council of Nurses. Position Statement on Antimicrobial Resistance. 2009 [Accessed at https://www.icn.ch/sites/default/files/inlinefiles/ICN_PS_Antimicrobial_resistance.pdf]. Accessed 21 Apr 2019.

22. Barlam TF, Cosgrove SE, Abbo LM, MacDougall C, Schuetz AN, Septimus EJ (6), et al. Implementing an antibiotic stewardship program: guidelines by the infectious diseases society of America and the society for healthcare epidemiology of America. Clin Infect Dis. 2016;62(10):e51-e77. doi: https:// doi.org/10.1093/cid/ciw118.

23. Fairall L, Bachmann MO, Lombard C, Timmerman V, Uebel K, Zwarenstein M, et al. Task shifting of antiretroviral treatment from doctors to primary-care nurses in South Africa (STRETCH): a pragmatic, parallel, cluster-randomised trial. Lancet. 2012;380(9845):889-98. https://doi.org/10.1016/S01406736(12)60730-2

24. Colvin CJ, Fairall L, Lewin S, Georgeu D, Zwarenstein M, Bachmann MO, et al. Expanding access to ART in South Africa: the role of nurse-initiated treatment. S Afr Med J. 2010:100(4):210-2

25. Georgeu D, Colvin CJ, Lewin S, Fairall L, Bachmann MO, Uebel K, et al. Implementing nurse-initiated and managed antiretroviral treatment (NIMART) in South Africa: a qualitative process evaluation of the STRETCH trial. Implement Sci. 2012;7:66.

26. Kredo T, Adeniyi FB, Bateganya M, Pienaar ED. Task shifting from doctors to non-doctors for initiation and maintenance of antiretroviral therapy. Cochrane Database Syst Rev. 2014;7:CD007331

27. Department of Health. Making a Difference: Strengthening the nursing, midwifery and health visiting contribution to health care. London: HMSO; 1999.

28. Humphreys A, Johnson S, Richardson J, Stenhouse E, Watkins M. A systematic review and meta-synthesis: evaluating the effectiveness of nurse, midwife/allied health professional consultants. J Clin Nursing. 2007;16:1792808. https://doi.org/10.1111/j.1365-2702.2007.01757.x].

29. Barnes S, Zirges C, Tomac D, Hall-Meyer K, Stein L, Barnden M, et al. The emerging role of the corporate or system-level infection prevention director for integrated delivery networks. Am J Infect Control. 2018. https://doi.org/ 10.1016/j.ajic.2018.10.020

30. Giles M, Parker V, Conway J, Mitchell R. Knowing how to get things done: nurse consultants as clinical leaders. J Clin Nurs. 2018;27(9-10):1981-93. https://doi.org/10.1111/jocn.14327.

31. Franks $\mathrm{H}$, Howarth M. Being an effective nurse consultant in the English National Health Service: what does it take? A study of consultants specializing in safeguarding. J Nurs Manag. 2012;20(7):847-57. https://doi. org/10.1111/j.1365-2834.2012.01353.x.

32. Charani E, Castro-Sanchez E, Sevdalis N, Kyratsis Y, Drumright L, Shah N, et al. Understanding the determinants of antimicrobial prescribing within hospitals: the role of "prescribing etiquette". Clin Infect Dis. 2013;57(2):18896. https://doi.org/10.1093/cid/cit212.

33. Gilchrist M, Wade P, Ashiru-Oredope D, Howard P, Sneddon J, Whitney L, et al. Antimicrobial stewardship from policy to practice: Experiences from UK antimicrobial pharmacists. Infect Dis Ther. 2015;4(Suppl 1):51-64. https:// doi.org/10.1007/s40121-015-0080-z

34. Broom A, Broom J, Kirby E, Scambler G. The path of least resistance? Jurisdictions, responsibility and professional asymmetries in pharmacists' accounts of antibiotic decisions in hospitals. Soc Sci Med. 2015;146:95-103. https://doi.org/10.1016/j.socscimed.2015.10.037.

35. Steffens E, Quintens C, Derdelinckx I, Peetermans WE, Van Eldere J, Spriet I, et al. Outpatient parenteral antimicrobial therapy and antibiotic stewardship: opponents or teammates? Infection. 2018. https://doi.org/10. 1007/s15010-018-1250-1.

36. Ashiru-Oredope D, Sharland M, Charani E, McNulty C. Cooke J; ARHAl antimicrobial stewardship group. Improving the quality of antibiotic prescribing in the NHS by developing a new antimicrobial stewardship Programme: start smart--then focus. J Antimicrob Chemother. 2012;67(Suppl 1):i51-63.
37. Greendyke WG, Carter EJ, Salsgiver E, Bernstein D, Simon MS, Saiman L, et al. Exploring the role of the bedside nurse in antimicrobial stewardship: survey results from five acute-care hospitals. Infect Control Hosp Epidemiol. 2018;39(3):360-2. https://doi.org/10.1017/ice.2017.255.

38. Grayson ML, Macesic N, Huang GK, Bond K, Fletcher J, Gilbert GL, et al. Use of an innovative personality-mindset profiling tool to guide culture-change strategies among different healthcare worker groups. PLoS One. 2015;10(10): e0140509. https://doi.org/10.1371/journal.pone.0140509.

39. Romero B, Fry M, Roche M. The impact of evidence-based sepsis guidelines on emergency department clinical practice: a pre-post medical record audit. J Clin Nurs. 2017;26(21-22):3588-96. https://doi.org/10.1111/jocn.13728.

40. Ouldali N, Bellêttre X, Milcent K, Guedj R, de Pontual L, Cojocaru B, et al. Impact of implementing National Guidelines on antibiotic prescriptions for acute respiratory tract infections in pediatric emergency departments: an interrupted time series analysis. Clin Infect Dis. 2017;65(9):1469-76. https:// doi.org/10.1093/cid/cix590.

41. Kirby E, Broom A, Gibson A, Broom J, Yarwood T, Post J. Medical authority, managerial power and political will: a Bourdieusian analysis of antibiotics in the hospital. Health (London). 2018;22(5):500-18. https://doi.org/10.1177/ 1363459317715775.

42. Ha DR, Forte MB, Olans RD, OYong K, Olans RN, Gluckstein DP, et al. A Multidisciplinary Approach to Incorporate Bedside Nurses into Antimicrobial Stewardship and Infection Prevention. Jt Comm J Qual Patient Saf. 2019. https://doi.org/10.1016/j.jcjq.2019.03.003.

43. Stanic Benic M, Milanic R, Monnier AA, et al. Metrics for quantifying antibiotic use in the hospital setting: results from a systematic review and international multidisciplinary consensus procedure. J Antimicrob Chemother. 2018;73(suppl_6):vi50-8.

44. Versporten A, Gyssens IC, Pulcini C, Monnier AA, Schouten J, Milanič R, et al. Metrics to assess the quantity of antibiotic use in the outpatient setting: a systematic review followed by an international multidisciplinary consensus procedure. J Antimicrob Chemother. 2018;73(Suppl_6):vi59-66. https://doi. org/10.1093/jac/dky119.

45. ANA \& CDC. Redefining the Antibiotic Stewardship Team: Recommendations from the American Nurses Association/Centers for Disease Control and Prevention Workgroup on the Role of Registered Nurses in Hospital Antibiotic Stewardship Practices. Silver Springs: American Nurses Association; 2017

46. Bishop J, Kong DC, Schulz TR, Thursky KA, Buising KL. Meeting the challenge for effective antimicrobial stewardship programs in regional, rural and remote hospitals - what can we learn from the published literature? Rural Remote Health. 2018;18(2):4442. https://doi.org/10.22605/RRH4442.

47. Bulabula ANH, Jenkins A, Mehtar S, Nathwani D. Education and management of antimicrobials amongst nurses in Africa-a situation analysis: an infection control Africa network (ICAN)/BSAC online survey. J Antimicrob Chemother. 2018;73(5):1408-15. https://doi.org/10.1093/jac/dky023.

48. Jeffs L, Law MP, Zahradnik M, Steinberg M, Maione M, Jorgoni L, Bell CM, Morris AM. Engaging nurses in optimizing antimicrobial use in ICUs: a qualitative study. J Nurs Care Qual. 2018;33(2):173-9. https://doi.org/10.1097/ NCQ.0000000000000281.

49. Gorman SK, Pro RS, Dresser LD, Con PE. Should Traditional Antimicrobial Stewardship (AMS) Models Incorporating Clinical Pharmacists with Full-Time AMS Responsibilities Be Replaced by Models in Which Pharmacists Simply Participate in AMS Activities as Part of Their Routine Ward or Team-Based Pharmaceutical Care? Can J Hosp Pharm. 2016;69(1):45-8.

50. Rawson TM, Moore LSP, Gilchrist MJ, Holmes AH. Antimicrobial stewardship: are we failing in cross-specialty clinical engagement? J Antimicrob Chemother. 2016;71(2):554-9. https://doi.org/10.1093/jac/dkv337.

51. CDC. The Core Elements of Antibiotic Stewardship for Nursing Homes. Atlanta: US Department of Health and Human Services, CDC; 2015. Available at: http://www.cdc.gov/longtermcare/index.htm

\section{Publisher's Note}

Springer Nature remains neutral with regard to jurisdictional claims in published maps and institutional affiliations. 